\title{
TRADISI MINAHASA TERKAIT DENGAN MAKANAN TRADISIONAL
}

\author{
Rina Palisuan Pamantung \\ r.pamantung@yahoo.com \\ Pascasarjana Program Studi Linguistik \\ Universitas Sam Ratulangi
}

\begin{abstract}
Food is regarded as important aspects of indigenous culture of Minahasa when viewed from various Minahasa cultural relics that still survive today. In addition, specific Minahasan traditional food is associated with social behavior which is very typical for a particular event in the culture, but still rarely written scientifically, especially in the field of linguistics.Empirical evidence shows that there is an ambiguity (overlap) on the appearance of the name of typical food between the party menu which still contains the original culture of Minahasa like Endo wangko 'holy day' or "Pengucapan" with a menu of food that are commercialized as the name of the food as a restaurant menu, inn or hotel, and vendor menu. In other words, the typical Minahasa food and beverage as a genuine Minahasan culture still appear on the religious function of culture, whereas on the other hand, Minahasan traditional food has appeared on the restaurant menu as a regular menu. The main problem in this study can be formulated as "How does the naming system of food that appears in Minahasa cultural traditions based on myths or folklore that have symbols and myths value and meaningful functioning as a cultural concept of Minahasa?". The conclusion is the concept of Minahasan culture especially Minahasan traditional food is a dynamic transformation that can be observed in Minahasan culture through the Minahasan traditional food naming system linulut vs non-linulut established or determined by a series of meaning components at the taxonomic hierarchy.
\end{abstract}

Keywords: minahasan traditional food, Minahasan culture.

\section{PENDAHULUAN}

Makanan tradisional Minahasa dianggap sebagai salah satu tradisi budaya yang masih bertahan saat ini. Selain itu, makanan dan minuman khas Minahasa terkait dengan perilaku sosial yang sangat khas untuk peristiwa tertentu dalam budaya, tetapi masih jarang ditulis secara ilmiah khususnya pada ilmu kebahasaan.

Kenyataan menunjukkan bahwa makanan dan minuman Minahasa merupakan salah satu peninggalan budaya yang awet, lestari, dan kokoh masih bertahan saat ini dengan pemunculan leksikon berupa nama makanan tradisional asli Minahasa serta variasi dan modifikasinya yang tidak berkurang tetapi terus bertambah. Asumsi dasar adalah nama makanan dan minuman khas Minahasa terus bertambah sehingga ada variasi nama berupa kombinasi kata yang beranekaragam berdasarkan modifikasi. Fakta empiris menunjukan bahwa ada keambiguan (tumpang tindih) pemunculan nama makanan dan minuman khas 
antara menu acara pesta yang masih mengandung budaya asli Minahasa seperti Endo wangko 'hari besar atau pengucapan' dengan menu makanan dan minuman yang dikomersialkan seperti nama makanan dan minuman sebagai menu rumah makan, menu penginapan atau hotel, dan penjual keliling. Dengan kata lain, di satu sisi makanan dan minuman khas Minahasa sebagai budaya asli Minahasa masih muncul pada fungsi religi budaya, sebaliknya di sisi lain makanan dan minuman khas Minahasa sudah muncul pada menu rumah makan sebagai menu biasa. Misalnya, nama makanan pangi. Pangi muncul pada acara pesta Endo wangko 'hari besar atau pengucapan" yang diadakan setiap tahun di Minahasa.

Namun, pangi juga dimasukkan sebagai salah satu menu makanan di rumah makan, penginapan, atau penjual keliling. Pangi juga muncul pada pesta yang lain, yakni maramba 'naik rumah baru', kawengen 'orang kaweng', lele'an 'permandian', hari kinatouwana 'hari jadi'. Pangi dapat dimodifikasi menjadi pangi ikang, pangi lobster, pangi udang sebagaimana nama makanan itu dikenal di wilayah Tombariri. Sehingga nama makanan khas Minahasa pangi sudah memiliki multi-fungsi. Terkait dengan hal itu, makanan dan minuman khas Minahasa bukan hanya mengandung konsep sistem budaya, tetapi juga sudah tergeser menjadi sistem religi atau sistem sosial karena nilai budaya pada tradisi Minahasa sudah diiterferensi dan ditambah dengan nilai ekonomi yang menghasilkan budaya Minahasa asli bernuansa materialisme. Dengan demikian, kompleksitas makanan dan minuman khas Minahasa terletak pada keberadaannya yang dianggap sebagai fenomena budaya pada umumnya di Indonesia yang juga memiliki gejala-gejala budaya dengan kekhasan dan keunikan atau sintesis khas tersendiri.

Sistem penamaan makanan dan minuman Minahasa yang terjadi sesuai dengan model serta peralihan konsep budaya yang mencerminkan dinamisme itu memerlukan taksonomi atau klasifikasi dalam kegiatan ilmiah agar leksikon nama makanan dan minuman yang bervariasi dapat dicermati dengan jelas dengan cara tertentu dan tampak memiliki keteraturan. Selain itu, konsep budaya makanan dan minuman khas Minahasa sekarang merupakan cerminan konsep budaya Minahasa asli pada masyarakat atau kelompok manusia di Minahasa yang mengalami proses evolusi yang pesat dan maju sehingga mulai mencapai proses materialisme seiring dengan globalisasi dan modernisasi. Sehubungan dengan masalah utama tentang "Bagaimana cara orang Minahasa menamai makanan sesuai dengan kebudayaan" tersebut, maka submasalah pada penelitian ini dapat diformulasikan sebagai berikut. 
Bagaimanakah sistem penamaan dari makanan yang muncul pada tradisi Minahasa berdasarkan mitos atau cerita rakyatnya yang memiliki simbol dan nilai yang berfungsi dan bermakna sebagai konsep budaya Minahasa?

Beberapa hasil penelitian yang terkait dengan taksonomi aspek makanan dan minuman khas Minahasa yang sudah dilakukan, antara lain oleh Adam (1976), Kalangi (1980), Graafland (1983), Karamoy (2002), dan Weichart (2004). Sementara itu, teori antropolinguistik (Foley, 1997) dan taksonomi (Hickerson, 1980) digunakan untuk menganalisis data makanan tradisional Minahasa. Metode penelitian adalah kualitataif dengan pendekatan etnografi.

\section{PEMBAHASAN}

Budaya Minahasa terkait dengan makanan secara fisik atu sebagai praktik makan-minum dapat dicermati pada cerita rakyat Minahasa yang menghasilkan sumber penamaan dan perbendaharaan kata (nomenklatur) berupa nama makanan dan minuman khas. Sumber nama atau referensi nama makanan dalam cerita rakyat ditunjang oleh praktik makan dan minum yang dilakukan masyarakat Minahasa sebagai kebiasaan dalam hidup. Penjelasan tentang nama makanan berdasarkan pada cerita rakyat dan praktik makan-minum sehari-hari dipaparkan sebagai berikut.

\section{Budaya Minahasa Terkait dengan Makanan Berdasarkan Cerita Rakyat Minahasa}

Mitos yang ada pada cerita rakyat tentang makanan biasa diterapkan pada kehidupan seharihari karena sudah dianggap sebagai kewajiban dan pedoman yang harus dipenuhi oleh masyarakat Minahasa agar "Opo Ni Empung" memberikan berkat dan kemujuran bagi masyarakat itu. Pelaksanaan acara atau kegiatan untuk memenuhi kewajiban atau kegiatan yang terarah terhadap pedoman sebagai nilai yang terkandung sebagai mitos dari cerita rakyat Minahasa dapat dinyatakan sebagai rasionalisasi mitos dengan beberapa pertimbangan bahwa makanan yang dikonsumsi saat ini selalu berlandaskan atau terarah pada pemikiran bahwa makanan itu merupakan makanan dan minuman yang diproduksi dan dikonsumsi oleh leluhur atau nenek moyang yang dipercaya seperti "Karema, Toar, dan Lumimuut".

Kebiasaan makan dan minum terhadap benda yang biasa dikonsumsi roh atau Opo $\mathrm{Ni}$ Empung sebagai gagasan mitos pada Minahasa adalah bentuk praktik sosial yang terjadi terus di Minahasa hingga saat ini. Hanya saja, bentuk praktik makan dan minum sudah menjadi konsep kebiasaan yang diadaptasi dan diadopsi sejalan dengan globalisasi dan modernisasi sehingga fakta yang terjadi mitos dari makanan dan minuman sebagai bentuk awal yang 
murni atau asli sudah ditambahi dengan asesori modern sehingga menghasilkan makanan dan minuman yang tercampur. Nama-nama makanan khas Minahasa sekarang lebih beragam atau bervariasi. Variasi bentuk nama makanan dan minuman yang muncul lebih memperkokoh nama makanan yang asli Minahasa. Nilai mitos tetap muncul pada penambahan nama makanan yang mucul sekarang. Penambahan nama makanan dan minuman merupakan hasil eksperimen dari pembuat makanan dan minuman dalam masyarakat Minahasa.

Ada beberapa cerita rakyat atau legenda yang digunakan sebagai acuan dalam penelusuran penamaan dari makanan dan minuman khas Minahasa karena dianggap sebagai mitos yang menjadi arahan, petunjuk, dan pedoman bagi masyarakat Minahasa sampai saat ini. Cerita-cerita rakyat itu adalah sebagai berikut.

1) I royor si koki'

2) Toar Lumimuut

3) Asal Usul Nama Amurang

4) Gunung Lokon dan Klabat

5) Si Naa en Jaa

6) Tumideng (Tumileng)

7) Lingkambene (padi yang melambai).

8) Kukua an doro' I esa make'et wo Lolok

9) Wuwun Sewe

10) Kukua an doro' Repi

11) Sisil an doro' anak tuama

12) Kukua an doro' Tjarema

13) Sisil an dumoro' in tjinamualian in tama i Maesa tanu in.

14) Sisil an si Wailan Tampilango

15) Panagian

Cerita rakyat Minahasa dari beberapa bahasa lokal di Minahasa ada kemiripan satu dengan yang lain. Misalnya, cerita tentang Toar dan Lumimuut ada pada semua bahasa daerah di Minahasa berdasarkan versi bahasa daerah itu sendiri. Penghuni pertama dipersonifikasikan dalam tokoh Karema, "teman untuk makan sirih-pinang" yang menata lingkungannya dengan membagikan lahan pertanian dari hutan dan mensugestikan pola peladangan berpindah. Dia berperan sebagai walian tu'a wewene, seorang imam wanita yang tua bagi orangtua primordial, To'ar-Lumimu'ut. Kategorisasinya (tua, wanita, imam tradisional), nama dan fungsinya mensugestikan ciri-ciri religius, suatu roh hutan otoktan dari masa lampau yang jauh. Sesudah menempatkan tatanan lingkungan, menunjukkan jalan 
kepada wanita muda, Karema, dan menjadi penengah bagi perkawinan To'ar-Lumimu'ut, dia menghilang dan berhenti memainkan suatu peranan yang signifikan kecuali sebagai suatu divinasi dari seorang imam tradisional.

Yang berbeda hanyalah setiap wilayah pemakaian bahasa daerah di Minahasa menceritakan tentang alam sekitar sesuai dengan ekologi lingkungannya atau kebiasaan hidup yang dialami oleh masyarakat pemakai bahasa daerah itu. Gagasan dan konten yang terkandung dalam banyak cerita rakyat di Minahasa, khususnya yang ditulis dalam bahasa Tontemboan, secara umum tergolong fiksi, mite atau mitos, dan sejarah. Masyarakat waktu itu menggambarkan keadaan objek-objek, seperti a) kisah-kisah leluhur manusia dan keadaan hewani; b) strategi dan cara menangkal bahaya dalam mempertahankan hidup; c) sikap, perilaku dan cara pandang sebagai sesama makhluk hidup; dan d) berbagai objek tertentu lainnya yang terkait dengan kearifan tradisional lokal dengan bercerita dari mulut ke mulut (Regar, 2012). Di antara cerita-cerita rakyat itu, termasuk "Wuu'un Sewe atau "Wuwung Sewe' sebagai pokok kilasan dalam tulisan ini. Wuwuri (atau wuwung) adalah nama leluhur marga Wuwung dan Wuwungan di Minahasa.

Menurut Levi-Strauss (2005: 5, 17), masyarakat demikian terutama dicirikan oleh kebahasaan tanpa tulisan. Mitologi cenderung statis dengan elemen-elemen dalam sistem tertutup, dan berbeda secara kontradiktif dengan histori yang bersistem terbuka. Versi tentang cerita rakyat atau legenda dalam bahasa Tondano adalah sebagai berikut.Cerita rakyat Minahasa yang berasal dari wilayah masyarakat berbahasa Tontemboan mirip dengan cerita rakyat pada masyarakat yang berbahasa Tombulu. Sementara itu, cerita rakyat Minahasa yang berasal dari wilayah pemakaian bahasa Tonsea mirip dengan cerita rakyat versi bahasa Tondano.Pada umumnya, cerita rakyat Minahasa bercerita tentang hal, peristiwa, atau kejadian yang terjadi di alam khususnya hutan yang terkait dengan penghuninya.

Mitos budaya terkait dengan makanan dan minuman khas Minahasa yang dipercaya dan diyakini sebagai pedoman dan arahan bagi orang Minahasa adalah cerita rakyat yang memiliki topik kehidupan manusia dengan alam, Opo yang Empunya alam, binatang di hutan yang mengandung kebenaran dalam hubungan secara horizontal dan vertikal. Sementara itu, tema dari cerita rakyat terdiri atas tema umum dan khusus. Tema umum dari cerita rakyat adalah permohonan doa pada Opo Ni Empung yang empunya alam untuk kemakmuran manusia melalui pemberian kesuburan serta menjauhkan manusia dari hal negatif. Selain itu, tema khusus dari cerita rakyat adalah kesuburan alam, mendapatkan hasil buruan yag banyak dari hutan, alam menghasilkan produksi yang melimpah atau manusia memperoleh kemakmuran dari hasil hutan berupa hasil binatang buruan, tanaman, dan sayuran yang 
melimpah ruah. Tema khusus yang lain adalah perumpamaan tentang sifat manusia secara negatif dan positif, yaitu rajin atau malas melalui nama binatang hasil buruan atau tanaman dari hutan atau kebun.

Perilaku manusia disamakan dengan sifat binatang tertentu. Binatang buruan hutan yang diumpamakan adalah binatang yang dikenal orang Minahasa karena sering ditangkap dan dijadikan makanan atau biasa dikonsumsi oleh manusia, misalnya Kukua an doro' I laku wo si Tjuse wo si Wolai, Kukua an doro' I tua' wo si Tjawok, sinisil, Kukua an doro' I weris wo si Wolani, sinisil, Kukua an doro' wo si linta', dan Kukua an doro' I tua' si talongka.

\section{Teks cerita rakyat Minahasa yang mengandung nama makanan dipaparkan sebagai berikut.}

1) Data tentang hutan sebagai sumber pengadaan makanan

(2-1) Asi tempo itu, pakasa se tou ma'angat an pa'kanen an talun.

'Pada waktu itu, umumnya orang masih mencari makanan di hutan'

(2-2) An talung loas, Toar ca meinde on ca kakalaan ole anoa, wawi, rusa (karapi), deng ular.

'Di belantara hutan, Toar tidak takut dan tidak dapat ditaklukkan oleh anoa, babi rusa, maupun ular'

(2-3) Sia matok, in tiang wangker temang in tana' supaya si bumi ca maten mabongkar sia kami ma piara wawi an in talung.

'Untuk menjaga supaya bumi tidak hancur, dia (Macawalang) mematok bambu besar, serta memelihara babi di gua'

(2-4) Si wioo lauste tumingkas muntep in talun.

'Si monyet segera berlari sembunyi di hutan'

(2-5) Ma'angat se tou makere pa'kanen nu manam t. anu (kele) wo'oi in talung,en anoa (karapi).

'Dengan berburu, orang akan dapat makanan lezat seperti babi hutan dan anoa' di hutan. 
Data kalimat (2-1), (2-2),(2-3), (2-4), dan (2-5) dalam teks cerita rakyat Minahasa yang sudah dipaparkan diatas menunjukkan adanya kata talung dan talun yang berarti hutan sebagai referensi atau sumber pengadaan bahan makanan. Kata talung dan talun memiliki satu arti, yaitu hutan. Kalimat (2-1) memperlihatkan bahwa talun 'hutan' menjadi tempat orang Minahasa mencari makanan dan minuman. Hanya pemunculan berbeda pada wilayah pemakaian bahasa lokal yang berbeda. Kata talung muncul pada bahasa Tontemboan, sementara kata talun berada pada kalimat dalam bahasa Tondano. Teks kalimat (2-2) ada nama binatang yang termasuk pada talung, yaitu anoa, babi rusa, dan ular. Pada kalimat (23), kata talung terkait dengan wawi (babi). Sementara itu, kata talun menjadi tempat persembunyian dari wioo 'babi hutan' pada kalimat (2-4). Nama-nama binatang itu adalah fauna dalam hutan yang menjadi sumber bahan makanan bagi masyarakat Minahasa. Kalimat (2-5) menunjukan bahwa orang Minahasa berburu di hutan untuk memperoleh makanan lezat. Setelah mencermati kelima kalimat yang berasal dari teks cerita rakyat Minahasa dalam bahasa Tontemboan dan Tondano, terlihat bahwa referensi bahan makanan di Minahasa adalah hutan. Kata hutan muncul dengan bentuk kata talung dan talun. Talung muncul pada bahasa Tontemboan, sementara talun adalah bahasa Tondano. Pada kedua kata itu, fonem pada akhir kata berbeda. Konsonan /n/ dan /g/ berada pada akhir kata talung, sebaliknya talun hanya berakhir dengan konsonan /n/. Ada variasi bunyi diftong /ng/dan /n/ pada pemakaian kata hutan dalam bahasa daerah di Minahasa.

2) Data tentang uma 'kebun' sebagai referensi sumber pengadaan makanan dan minuman khas Minahasa.

(2-6) Awoya memaja-maja' oka sera, ja itjasumpoka-mai a lawi i maesa-sende'en ni uma.

'Karena tergesa-gesa dia melupakan sayur di rumah'

Data (2-6) menunjukkan kalimat yang mengandung kata sende'en yang berarti sayur. Kata sende'en muncul serangkai dengan kata maesa.

3) Data tentang sera 'ikan'

(2-7) Saat sia mengat sera' en ma'angat karapi kuala lilingana an suara tou walina an buru'na.

'Sementara dia berburu dan mencari ikan di sungai, dia mendengar suara orang lain yang berada di seberang dia berdiri'. 
'Mereka berbicara tentang ikan yang akan dimasak lalu membuat ikan emas menjadi makanan'

(2-9) Sia (Tiwow) senang mengat binatang, en ma'angat sera' an kuala.

'Tiow Mararatu adalah orang yang senang sekali berburu, dan mencari ikan di sungai'.

Data kalimat (2-7), (2-8), dan (2-9) dari teks cerita rakyat Minahasa memperlihatkan munculnya kata sera' 'ikan' yang di ambil dari sungai. Pada kalimat (2-7) dan (2-9) menunjukkan bahwa orang Minahasa yang bernama Tiow Mararatu senang berburu dan mengambil ikan dari kuala 'sungai'. Kuala 'sungai' merupakan sumber pengadaan bahan makanan di Minahasa. Pada kalimat (2-8) menunjukkan bahwa ikan yang dimasak oleh orang Minahasa adalah pongkor 'ikan emas'. Pongkor 'ikan emas' adalah ikan yang memiliki nilai lebih tinggi dari jenis ikan lain seperti mujair. Ikan emas sering dihadirkan pada pesta dengan nama makanan woku woka ikang mas. Makanan itu dimasak dengan bumbu woku tetapi dibungkus dengan daun woka. Harga ikan emas paling mahal dari jenis ikan yang berasal dari air tawar.

4) Data tentang binatang peliharaan

(2-10) Sia marior-rior kumi 'ito se karapina karapi se asu piarana.

'Dia segera berkemas dan bergegas-gegas, dan mengikuti teman-temannya, sekaligus anjinganjing peliharaannya',

Kalimat pada data yang sudah dipaparkan diatas memperlihatkan bahwa asu 'anjing' adalah jenis binatang yang dipelihara manusia. Kata asu 'anjing' dikenal dan dipakai dalam pemakaian bahasa daerah di Minahasa. Walaupun asu 'anjing' menjadi binatang peliharaan manusia tetapi asu 'anjing' kadangkala dipelihara untuk dijadikan bahan makanan. Asu 'anjing' sebagai jenis binatang berkaki empat menjadi salah satu sumber bahan makanan dari makanan $R w$. Asu 'anjing' dipelihara untuk diambil daging dan darahnya. Berbeda dengan jenis binatang lain, misalnya wawi 'babi' yang diambil seluruh bagian tubuhnya, bukan hanya daging saja.

5) Data tentang sayur bene', tande

(2-11) Ja a si tana' itu usewano i Inang wo si Amanga i megigioan em batuna in tinanem, tanuo-mai im bene', tande, sesende'en, wo m bua'na in tjaju wangker 
'Di tanah yang berbatu, Ibu dan bapak menanam padi, jagung, sayur-sayuran dan buah tumbuh menjadi besar'

Kalimat pada teks cerita rakyat Minahasa memperlihatkan bahwa bene' 'padi', tande ' jagung', sesende'en 'sayur', dan bua'na 'buah' yang ditanam di tanah yang berbatu dapat tumbuh menjadi besar. Hal itu menunjukan tanah Minahasa subur bila ditanami tanaman apa saja. Terkait dengan makanan dan minuman khas Minahasa, padi, jagung, sayur-sayuran, dan buah-buahan menjadi bahan makanan utama dalam proses penamaan makanan dan minuman khas Minahasa. Tanaman padi, jagung, sayuran, dan buah-buahan dianggap sebagai nama benda yang mengalami proses perluasan, elaborasi, dan prafrase bila dinamai masyarakat Minahasa sesuai konvensi dan kognisinya. Nama makanan dan minuman khas Minahasa muncul dari benda yang dinamai itu. Selanjutnya nama makanan lebih dikenal secara luas, bila nama itu muncul pada praktik makan minum sebagai kebiasaan hidup yang dilakukan secara rutin di Minahasa.

6) Data tentang tanaman padi

(2-12)Tou se Kayoba an repewana sinanem wene'an waktu sesuai setou kayobaan nyaya an dangkain wene' pya sendeng minor se tou an kayobaan meros dan kayangan newet wene' na.

'Orang dari bumi menanam padi sesuai waktu yang diajarkan oleh surga dalam memperlakukan padinya'

Kalimat pada teks cerita rakyat terkait dengan asal mula wene 'padi' yang berasal dari kayangan atau surga. Kalimat itu mengandung kata wene 'padi' yang menjadi makanan utama pada kategori kan bagi masyarakat Minahasa. Teks cerita rakyat ini dianggap sebagai suatu bukti awal pemunculan nama makanan yang berasal dari padi.

7) Data tentang nate 'hati'

(2-13)Niaku wararante kuman nate in tongo

'Saya sering makan hati dari binatang hutan'

Kalimat pada data (2-13) dari teks cerita rakyat yang berbahasa Tondano memperlihatkan bahwa orang Minahasa biasa makan nate in tongo 'hati binatang' yang berasal dari hutan. 
8) Data tentang bulu 'bambu'

(2-14) Si Jaa sumiloo pa'kanan am bulu an kesot in bale.

'Si Jaa membuat makanan dalam bambu di luar rumah'

\section{(2-15) Si Naa semeloo in kukis cucur}

'Si Naa membuat kue cucur'

Pada kalimat (2-14) dan 24-15) terlihat pemakaian kata sumiloo dan semeloo terkait dengan pembuat makanan yang berbeda jenis kelamin pria dan wanita. Kata bulu 'bambu' digunakan sejajar dengan sumiloo yang berarti diluar rumah. Kata itu berbeda dengan semiloo yang berarti di dalam rumah. Preposisi sumiloo dan semiloo terkait dengan jenis kelamin dari pelaku atau pembuat makanan. Kalau pembuat makanan seorang pria maka kata yang muncul adalah sumiloo diikuti oleh kata an kesot dan bale 'rumah' artinya di luar rumah. Sementara, semiloo yang berarti di dalam rumah selalu mengacu pada pembuat makanan berjenis kelamin wanita yang membuat makanan di dapur. Bila dicermati dari kognisi masyarakat Minahasa, perbedaan penggunaan kata di luar rumah dan di dalam rumah mengartikan suatu dikotomi antara wanita dan pria.

Kata di luar rumah dan di dalam rumah menjadi komponen pembeda antara jenis kelamin wanita dan pria. Ada binary oposition pada kata itu. Kata di luar rumah sebagai acuan bagi pria, sebaliknya di dalam rumah menjadi acuan bagi wanita terkait dengan orang yang membuat makanan di Minahasa. Selain itu, di luar dan di dalam menjadi acuan binary oposition bagi pekerjaan pria dan wanita di Minahasa.

Data (2-16) memperlihatkan kata upe 'air nira' sebagai nama minuman yang diambil di hutan yang biasanya dipakai sebagai pelengkap bila makan.

9) Data tentang pesta pengucapan syukur

(2-17) Kanaramen ne rior sa nimakaupuknio waya ne tou matua wo se o-kipek, tuana weweno raiwana linangkoi nerur wanano patar kalumeosi nasa; ibo, maengket pahakiakiten ni Italian.

'Lalu Pandagian kembali melanjutkan upacara ritual maengket dengan nyanyinyanyian sampai pagi'

(2-18) Si walian wo se tou wa-ya niakiweho wia si Empung satoro luka-lukarani waya, pawue-wunni kaaapito i sigi wangko sapa waya rai welieni ni Empung wia nosea. 
' Hal itu didengar oleh para Opo dan menurunkan tali rotan dari langit ke bumi sebagai hadiah kesuciannya'

(2-19) Si kekekou yai. si', raino warengkuku nako, likita namualiao tou laker loit wo tuiao.

' Si Kekekou memberikan uang banyak karena mereka selalu membuat acara syukuran' (2-20) Niana waya pakantar nea wia masambo wo maengket.

' Ia bernyanyi-nyanyi pada acara syukuran dengan tarian maengket'

Data (2-17), (2-18), (2-19), dan (2-20) menunjukkan adanya kata yang mengandung arti ucapan syukur yang dilaksnakan di Minahasa. Pada acara syukuran selalu dihadirkan tarian maengket sebagai sebuah bentuk ucapan syukur pada OpoNi Empung yang sudah melimpahkan berkat bagi masyarakat Minahasa. Tarian yang diiiringi dengan syair nyanyian dalam Maengket mengandung makna budaya yang dalam karena tujuannya adalah mempersembahkan yang terbaik bagi Opo Ni Empung sebagai Tuhan Allah di Atas yang merupakan sosok empunya alam yang didiami masyarakat Minahasa.

Berdasarkan pada kalimat-kalimat teks pada cerita rakyat Minahasa maka perbendaharaan kata atau leksikon terkait dengan makanan khas Minahasa yang muncul adalah sebagai berikut.

1) Wawi 'babi'

2) Sera' 'ikan'

3) Pongkor' ikan emas'

4) Wene 'padi'

5)Sende'en 'sayur'

6) Buana 'buah'

7) Kalapa 'kelapa'

8) Bene' 'padi'

9) Bulu'd 'bambu'

10) Wioo 'babi hutan'

11) Masambo 'tarian pada pesta panen'

12) Maengket 'tarian pada pesta panen'

13) Babi

14) Nimakaupuknio 'pesta panen'

15) Empung satoro 'pesta ucapan syukur'

16) Kekekou 'burung puyuh pembawa padi' 
17) Nasi jaha 'kue nasi jahe yang dimasukkan di bambu'

18) Cucur 'kue cucur'

19) Bulu 'bambu'

20) Anoa

21) Rusa

22) Ular

23) Tande 'jagung'

24) Asu 'anjing'

Leksikon (nomenklatur) dalam cakupan makanan yang muncul pada teks dapat dikategorikan pada beberapa jenis benda adalah sebagai berikut.

i) Jenis tanaman:

Wene 'padi'

Tande 'jagung'

Bene 'padi'

ii) Jenis binatang:

Wawi 'babi'

Anoa

Rusa

Ular

Asu 'anjing'

iii) Jenis makanan:

Sera' 'ikan'

Pongkor 'masakan ikan emas'

Nasi jaha 'kue nasi jahe dalam bambu'

Cucur 'kue cucur'

v) Jenis acara ritual:

Nimakaupuknio ' pesta panen', maengket 'tarian pada pesta panen'.

Empung satoro 'pesta ucapan syukur', masambo 'tarian pada pesta panen'

vi) Jenis unggas:

Kekehou 'burung puyuh'

Leksikon yang sudah terdaftar diatas, yang muncul pada teks cerita rakyat, digunakan pada upacara ritual, dilaksanakan oleh masyarakat Minahasa yang memiliki beberapa bahasa 
daerah. Pada praktik upacara ritual Minahasa nomina itu memiliki nilai mitis sehingga dijadikan mitos yang harus digunakan dan dihadirkan pada acara penting di Minahasa.

Deskripsi tentang cerita rakyat Minahasa di atas mengandung mitos yang dipercaya oleh orang Minahasa sampai sekarang ini. Mitos menjadi keyakinan dan menjadi pedoman bagi masyarakat Minahasa. Sebagaimana teori yang dikemukakan oleh Barthes tentang mitos bahwa mitos diaktualisasikan dan dimanipulasikan oleh pengguna mitos. Cerita rakyat yang menjadi mitos terkait dengan makanan dan minuman khas Minahasa berupa daging-dagingan dari binatang buruan dari hutan, ikan, pohon-pohonan atau tanaman dari hutan, dan tanaman di ladang, serta tanaman hutan yang menghasilkan minuman terlihat nyata ada pada cerita rakyat yang menjadi legenda sebagai pengantar atau dongeng bagi anak-anak di Minahasa zaman dulu, tetapi sekarang hanya menjadi dokumentasi atau arsip bagi daerah, nasional atau internasional, bahkan sudah menjadi materi pada website. Mitos tentang makanan dan minuman dalam cerita rakyat atau berasal dari cerita rakyat menjadi bukti autentik atau historical evidence yang memiliki nilai filosofis-historis bagi masyarakat Minahasa. Mitos ini diaktualisasikan pada praktik keseharian masyarakat sehingga menjadi kebiasaan atau rutinitas dalam kehidupan sosial masyarakat Minahasa. Anggota masyarakat atau orang Minahasa secara individual atau berkelompok selalu menjunjung tinggi nilai dari mitos yang ditemukan pada cerita rakyat. Mitos tentang makanan Minahasa berfungsi pada praktik kultural keagamaan dan keseharian sebagai tradisi budaya Minahasa.

\section{Menu Makanan Harian}

Menu Makanan Harian

Kan

sende'en

serza

Hidangan yang diambil pada urutan kedua saat makan ialah sende'en 'sayuran'. Yang disantap setiap hari adalah jenis sayuran hijau, seperti kangkung, pakis, bayam, gedi, dan daun serta bunga pepaya. Biasanya menu harian hanya terdiri atas kan 'nasi' dan sende'en 'sayur' di meja petani, dan karena itu memakan hidangan ini disebut sumende 'hanya makan sayur'. Dari sini orang mengasosiasikan hubungan perkawinan dengan sayuran. Sekarang ini, kebanyakan anak-anak tidak (malah menolak) makan sayur. Pada masa krisis, khususnya saat perang Permesta di tahun 1950-an, masyarakat mengalami kekurangan beras sehingga banyak jenis sayuran yang ditemukan di lingkungan sekitar dicampurkan bersama-sama dalam belanga, dan hidangan inilah yang dinamakan tinu'tuan (secara harafiah 'yang dimasak'). 
Masa kini hidangan ini menjadi bergengsi sebagai "bubur Manado", dan disajikan sebagai pelengkap pada saat minum kopi, tetapi tak pernah sebagai hidangan utama saat makan siang. Versi lain yang diungkapkan oleh Weichart (2004) adalah tinu'tuan mulai dikenal masyarakat Minahasa pada zaman penjajahan Jepang. Orang Minahasa yang bersembunyi di hutan hanya mengandalkan tanaman sayuran apa saja yang ada di lingkungan sekitarnya, sehingga makanan bubur sayur tersebut memiliki nama yang bervariasi atau beragam menurut daerah wilayah pemakaian bahasa daerah di Minahasa ataupun skala wilayah pedesaan atau kecamatan.

(2-28) Si pinangei'lek nio' ca kinokiitan makere kasoeang.

'Permintaan itu sebagai pesanan penting supaya tidak mendapat musibah'

(2-29) Se pasangan nio' (Naa en Jaa) si tawoyen nio’.

'Pasangan suami istri Jaa dan $\mathrm{Na}$ 'a menyanggupi permintaan itu'

(2-30) Si Jaa sumiwo pa'kanen am bulu an kesot in bale.

' Si Jaa membuat makanan di bambu yang dibakar di luar rumah'

(2-31) Si Naa sumiwo in kukis cucur.

'Si Naa membuat kue cucur'

(2-32) Tumenge 'cur' sa sumiwo an dumping

'Cucur dibuat dalam wajan'

(2-33) Opo mesale-sale on cawane kasoeang.

'Dewa gembira ria sehingga tidak ada musibah'

Teks cerita tentang tinutu'an

Teks cerita tinu'tuan berarti bubur sayur dalam bahasa Tontemboan yang menjadi pemikiran masyarakat pada wilayah Tontemboan (bubur sayor, sayor-sayoran, bahasa Tontemboan):

(2-34) Adat indior pa'kanen nio (tinutuan) kuman setela selesayo ato meklaro acara pesta ato duka atao acara-acara wangko walina karna tinutu'an, pa'kanen mengandung sayor-sayor. 
'Kebiasaan dulu makanan tinu'tuan (sayur-sayuran) ini dimakan setelah acara pesta, duka, atau acara besar lainnya karena tinutu'an mengandung sayur-sayuran' (cr tntn-1)

(2-35)Tujuanna tanya kelaro acara pesta wangko walina slalu mekekelimoko sumiwo tinutu'an.

'Biasanya setelah acara pesta, orang membuat tinu'tuan untuk dimakan'

(2-36) Karna pa'kanen pesta keli mengandung lemak on daging2an ma suut intou.

'Karena makanan pesta banyak mengandung lemak pada daging yang membuat orang 'pastiu' (jenuh/bosan) atau merasa berminyak (penuh minyak) di tubuhnya'

Selain sayur ada juga kebiasaan makan di Minahasa yang mengenal ikan dari danau atau ikan air tawar dan ikan laut. Bumbu atau rempah yang biasa di- campurkan pada adonan adalah bumbu rampa campur 'rempah campur'. Bumbu ini dapat divariasikan pada berbagai jenis ikan atau daging. Cara memasak menggunakan media berupa daun dan bukan diisi dalam bambu sehingga dinamakan woku. Bumbu woku dikenal secara umum di Minahasa sehingga ada beberapa versi bumbu woku tergantung pada etnis pembuat yang memiliki bahasa daerah. Teks-teks yang mempresentasikan adanya makanan label non-linulut dengan bumbu woku adalah sebagai berikut.

Label bumbu woku (versi Tontemboan) memiliki variasi bentuk leksikal berupa woku daong, woku woka, dan woku blanga.

Teks yang mempresentasikan woku dapat dilihat pada data berikut:

(2-37)Woku daong biasana pa bungkusen in daong punti.

'Woku daong biasanya dibungkus dengan daun pisang atau daun woka (kelapa, palem)'. (wk-1)

\section{(2-38) Sera' biasana pabungkusen in daong woka'}

'Ikan biasanya dibungkus dengan daun woka atau janur atau kelapa'.

(wk -2) 
Sejumlah teks yang sudah dipresentasikan itu menjadi dasar filosofi bagi masyarakat Minahasa sehingga nama makanan non-linulut diterapkan pada masyarakat Minahasa sampai saat ini. Pada tataran linguistik maka makanan label non- linulut dapat dikonfigurasikan sebagai taksonomi hierarkis.Sejumlah teks penunjang dalam penerapan dari nama makanan non linulut yang hadir pada acara syukuran, menu harian, dan menu rumah makan. Bila dikaji dengan teori medan makna pada taksonomi hierarkis maka label non-linulut dapat dicermati pada pembahasan sebagai berikut Label makanan non-linulut merupakan label nama untuk makanan di luar dari linulut yang berarti jenis nama makanan sebagai perangkat leksikal yang tidak dibakar di perapian, tetapi terdapat beberapa variasi atau ragam dari komponen makna di luar cara memasak dengan media atau alat bambu dan perapian.

Manfaat praktis dari leksikon nama makanan non-linulut dapat dicermati pada pemunculan nama makanan sebagai hidangan pada acara syukuran, menu harian, dan menu rumah makan. Bentuk dan fungsi terlihat dan tampak sebagai nama makanan dan minuman khas Minahasa sehingga muncul sebagai sistem penamaan. Penjelasan dari nama makanan non- linulut adalah sebagai berikut. Makanan non-linulut yaitu makanan selain makanan yang dimasak di bambu, seperti label woku, label r.w, label garo rica, label gohu, label dabudabu, label kuah, dan label bubur sayur. Manfaat praktis dari nama makanan non-linulut adalah jenis makanan yang muncul pada acara syukuran non-pesta.

Tinu'tuan sebagai salah satu bagian non-linulut yang pada mulanya hanya bubur sayor, tetapi akhirnya terangkat posisinya sebagai menu acara syukuran atau pesta kecil-kecil secara formal dan tidak formal. Makanan ini muncul hanya pada acara yang diselenggarakan oleh kelompok lingkungan tertentu yang saling mengenal atau matuari atau katuari' tong deng tong” (kita saja) berupa syukuran di lingkungan antarteman, keluarga kerabat (rukun), atau rutinitas acara ibadah gereja di kolom (rayon). Makanan tinu'tuan tidak pernah dimunculkan pada acara pesta besar seperti "orang kaweng" atau "Pengucapan Syukur" karena secara implisit ada perasaan yang "direndahkan" bila memunculkan sajian makanan ini untuk tamu. Jadi, kepercayaan yang dianut masyarakat Minahasa adalah pantang (tidak boleh) memunculkan makanan tinu'tuan pada acara pesta.

\section{Menu Makanan Pesta}

Menu Makanan Pesta

Kan serza sende'en

Daging-dagingan muncul pada pesta secara formal dan tidak formal. 
Data yang memprestasikan pemunculan daging-dagingan pada setiap acara syukuran dengan simbol berkat dapat disajikan di bawah ini.

Daging-dagingan muncul pada pesta secara formal dan tidak formal.

Data yang mempresentasikan pemunculan daging-dagingan pada setiap acara syukuran dengan simbol berkat dapat disajikan di bawah ini.

Daging-dagingan muncul pada pesta secara formal dan tidak formal.

Data yang mempresentasikan pemunculan daging-dagingan pada setiap acara syukuran dengan simbol berkat dapat disajikan di bawah ini.

(2-39 )Wawi e pahpiaraan ne opo, tanu unuwune tua' puuna- ka 'pa sirita punna'

'Babi adalah binatang piaraan Dewa, $(\mathrm{w}-1)$

Nitumo seza wawi mamoali kakanen lumayak.

' Oleh karena itu, babi biasa dimakan orang'

\section{(2-41) )Wawi kakanen ne Opo.}

Babi adalah makanan para Dewa

Selain itu, salah satu contoh keterkaitan hewan babi dengan kehidupan orang Minahasa dalam pengertian bahwa hewan babi mendapat posisi penting pada upacara adat khusus pada zaman pemerintahan Minahasa dahulu yang berlangsung sebelum abad 16 . Upacara adat dilakukan oleh Kesatuan Organisasi pemerintahan Minahasa dengan cara membagikan potongan-potongan hewan kurban babi kepada pejabat pemerintahan. Setiap potongan dari hewan memiliki simbol tertentu. Ketua Potu'usan dewan tua-tua mendapat 'kaki belakang dan depan' yang disebut kembeng; Kepala Walak atau Ukung Wangko 'Hukum Besar' mendapat 'rahang bawah'; Kepala perang atau Kapitan atau Teterusan mendapat Lolas atau kawi'i 'daging punggung kiri'; Gumigrot atau hakim mendapat Lolas kakan 'daging punggung kanan'; Walian in uma (wanita) atau Walian lele'en (pria) mendapat Salaksakkawi’i 'rusuk kiri'; Walian Peposanan atau pemimpin Walian (pria atau wanita) mendapat Salaksak Kakan 'rusuk kanan'. 'Kaki babi' sebagai simbol ke arah tujuan kehidupan masyarakat untuk dewan tua-tua. 'Kepala babi' simbol dari berpikir (gegenang), ekonomi (makan) dan sekaligus berperang (menggigit) dan berbicara kepada masyarakat. 'Otot pungggung' sebagai simbol dari menyerang sesuai dengan hukum-hukum berperang untuk Tona'as sebagai kepala Walak. 'Rusuk' sebagai simbol pelindung hati dan jantung 
atau nyawa manusia menjadi urusan dari para Walian pendeta agama suku (Ingkiriwang, 2004).

Budaya Minahasa terkait dengan makanan tradisional Minahasa maka nama-nama makanan Minahasa sebagai perbendaharaan kata (leksikon) dimasukkan pada setiap level tersebut sehingga tampak dikotomi yang terjadi pada makanan dan minuman khas Minahasa. Goodenough (1964) menyatakan bahwa budaya adalah fenomena mental. Sebagai organisasi dari fenomena material. Budaya masyarakat terdiri atas apa saja yang diketahui atau dipercaya serta dijalankan dengan cara yang dapat diterima oleh anggotanya. Makanan dan minuman yang diproduksi dan dikonsumsi masyarakat Minahasa selalu dibatasi oleh budaya Minahasa pada masa lalu. Tetapi sekarang, budaya Minahasa sudah mengalami pergeseran dan perluasan sesuai dengan perkembangan zaman globalisasi. Levi Strauss sudah menyatakan bahwa mencermati struktural linguistik pada ranah budaya selalu bersifat oposisi biner (binary opposistion).

Bila membicarakan budaya Minahasa yang terfokus pada makanan Minahasa maka makanan minuman berasal dari sumber alam, yaitu hutan dan kebunpernyataan itu diperkuat oleh Renwarin. Sementara, nama makanan untuk manusia dan binatang dibedakan. Makanan untuk manusia dibedakan juga dengan Yang punya alam atau Opo, ataupun yang menghuni alam. Makanan untuk manusia disebut kaanen atau pahkanen. Makanan untuk binatang juga disebut kaanen atau pahkanen. Fakta yang terjadi adalah makanan untuk manusia berbeda spesifikasinya karena makanan untuk binatang kebanyakan adalah daun-daunan dari tanaman alam. Setelah mencermati paparan tentang sumber otentik berupa teks cerita rakyat dan teks berdasarkan hasil wawancara langsung dengan informan, serta resep makanan maka sumber pengadaan makanan dan minuman khas Minahasa sebagai referensi adalah talung 'hutan' dan uma 'kebun'. Kalangi (1979) sudah menjelaskan bahwa hutan adalah sumber pengadaan makanan dan minuman khas di Minahasa

Pada teks tentang air nira yang disebut lepen, timpa atau saguer muncul beberapa istilah kata sapaan (terms of address) atau penyebutan terhadap seseorang yang dihormati atau disegani sekali. Nama panggilan atau sapaan untuk "Yang di atas" adalah Opo WananAtas sebagai Dewa tertinggi atau Empung Wailanwangko 'Yang Berkuasa'. Opo juga sering disamakan dengan inopo 'leluhur' atau dotu. Jadi, leluhur orang Minahasa yang bernama Karema, Toar, dan Lumimuut disebut dengan Opo.Keseluruhan tradisi budaya yang sudah dideskripsikan tersebut merupakan konsep budaya Minahasa terkait atau dalam cakupan makanan dan minuman Minahasa pada masa lalu dan kini. Penjelasan dan pembahasan lebih lanjut adalah kajian makanan dan minuman khas Minahasa yang terlihat 
jelas sekarang ini sebagai percampuran antara budaya asli Minahasa dan interferensi atau pengaruh globalisasi, dan modernisasi yang terjadi dengan deras di Republik Indonesia khususnya di Provinsi Sulawesi Utara, yakni di Minahasa.

\section{SIMPULAN}

Berdasarkaan pada paparan yang sudah dijelaskan diatas maka simpulan yang dapat diambil, yaitu sebagai berikut.

Tradisi budaya terkait dengan makanan tradisional Minahasa adalah konsep budaya Minahasa yang dapat dicermati pada peradaban Minahasa melalui adanya fakta bahwa simbol makanan dan minuman khas Minahasa sebagai "mediator" antara manusia dengan Opo Niempu 'Yang Empunya Alam' pada masa lalu berubah menjadi simbol "berkat" atau "ucapan syukur" secara religi (makna yang tersirat) dan sistem sosial karena yang tertinggal sekarang adalah kebiasaan makan dan minum dengan menu makanan dan minuman khas Minahasa sebagai rutinitas mobilitas sosial dalam kehidupan masyarakat Minahasa. Menu harian terdiri atas kan 'nasi', sende'en 'sayur', dan serza 'protein'. Sementara itu, makanan pada menu pesta terdiri atas kan 'nasi', serza ' protein', dan sende'en 'sayur'. Posisi sende'en berubah pada menu pesta menjadi makanan terakhir atau tidak terlalu diwajibkan, karena merupakan alternatif saja. Kalau tersedia di meja sebagai hidangan dianggap melengkapi menu pesta. Jadi sende'en hanya berupa makanan alternatif saja. Sebaliknya pada menu makanan harian, sende'en dianggap makanan pelengkap dari nasi kan, protein adalah menu makanan yang terakhir, atau alternatif saja.

Walaupun demikian, hal itu memperlihatkan transformasi dinamis pada kehidupan masyarakat Minahasa terkait dengan pertambahan nama makanan dan minuman yang menyebabkan sehingga budaya Minahasa awet dan lestari sepanjang masa. Proses penalaran atau berpikir induktif didukung oleh pandangan bahwa alam di Minahasa permanen yang terdiri atas pegunungan dengan talun 'hutan' dan uma 'kebun' menjadi sumber penamaan pada klasifikasi makanan dan minuman khas Minahasa berupa label linulut dan non-linulut. Klasifikasi itu didasarkan pada fungsi pemanfaatan makanan harian dan pesta. Peradaban yang mengalami transformasi dinamis di Minahasa merupakan multifarious karena adanya tambahan menu makanan tradisional Minahasa berupa menu rumah makan, menu kantin, menu tempat penginapan atau hotel, dan menu penjual keliling. Oleh karena itu, sistem penamaan makanan dan minuman khas Minahasa label linulut vs non-linulut dibentuk atau ditentukan oleh beberapa komponen makna berupa komponen bahan makanan, alat atau media yang digunakan dalam memasak, cara memasak, lokasi pembuatan makanan 
berdasarkan pemakaian bahasa lokal di Minahasa, sejarah dan kedatangan etnis Minahasa, dan nama manusia sebagai parameter atau indikator yang dapat dikonfigurasikan pada taksonomi hierarkis.

\section{DAFTAR PUSTAKA}

Aarts dan Aarts. 1978. Grammatical English. New York: McMillan Press.

Adam, I. 1976. Adat-Istiadat Suku Bangsa Minahasa. Jakarta: Bhrarata.

Allan, Keith. 1986. Linguitic Meaning Vol.1. London: Roudledge \& Kegan Paul.

Casson, R. 1981. Language, Culture, and Cognition: Anthropological Perspectives. New York: McMillan Publishing Co, Inc.

Clark, E.V. 1993. The Lexicon in Acquitition. Cambridge: Cambridge University Press.

Cruse, D.A. 1991. Lexical Semantics. Cambridge: Cambridge University Ppress.

Djajasudarma, F. 1993. Semantik I-II. Bandung: PT Rafika Aditama.

Foley, W. 1997. Anthropological Linguistics in Introduction. USA: Blackwell publisher.

Halliday, M.A. K. \& Hasan, R. 1985. Language, Context, and Text: Aspect of Language in A Social-Semiotic Perspective. Victoria: Deakin University.

Hanafie, Sitti. 1992. Kelas Kata dalam Bahasa Bugis: Kajian Morfologi Lingkup Kelas Verba, Adjektiva, dan Nomina (disertasi). Makassar: PPS Unhas

Karamoy, O. 2002. Peristilahan atau Kosa Kata yang Digunakan Orang Minahasa pada Komuditas Pertanian dalam Pembuatan Makanan Tradisional. Dalam Duta Budaya. No. 53/54. Manado: Fakultas Sastra, Unsrat.

Ingkiriwang, J. 2007. Manusia dan Kebudayaan Minahasa. Manado: Percetakan UNSRAT. Leech, G. 1971. Semantics. London: Penguin Books.

Lehrer, A. 1974. Semantic Fields and Lexical Structure. Amsterdam: North Holland Publishing Company

Lutzeier, P.R. 1983. The Relevance of Semantic Relations Between Words for the Notion of Lexical Field. Theoretical Linguistics 10: 147 - 178.

Lyons, J. 1977. Semantics. I - II. Cambridge: Cambridge University.

Manoppo, G. 1983. Bahasa Melayu Surat Kabar di Minahasa pada Abad ke-19. (disertasi). Jakarta: Universitas Indonesia.

Masinambouw, E. K. M. 2002. Semiotik: Kumpulan Makalah Seminar. Jakarta, Depok: Pusat Penelitian Kemasyarakatan dan Budaya Lembaga Penelitian Universitas Indonesia. Matthews, P.H. 1978. Morphology: An Introduction to the Theory of the Word-Structure. London: Cambridge University Press. 
Nida, E. 1975. Componential Analysis of Meaning. The Haque: Mouton

Palmer, E. 1976. Semantics. Great Britain: Cambridge University Press.

Pamantung, R. 2015. Taksonomi Nomina Aspek Makanan dan Minuman Khas Minahasa. Bali : Pascasarjana Universitas Udayana.

Pastika, I. W. 2005. Linguistik Kebudayaan: Konsep dan Model. Dalam Linguistika Vol. 12. No.22. Denpasar: Program Studi Magister dan Doktor Linguistik Universitas Udayana.

Rondonuwu, B. 1983. Minahasa Tanah Tercinta. Manado: Yayasan Karya Pemuda Sulut, KNPI DPD Minahasa.

Renwarin, R. 2007. Matuari Wo Tonaas. Dinamika Budaya Tombulu di Minahasa. Jilid I: Mawanua. Jakarta: Penerbit Cahaya Pineleng.

Salzmann, Z. 1993. Language, Culture, and Society: Introduction to Linguistic Anthropology. USA: Westview Press.

Samarin, William J.. 1988. Ilmu Bahasa Lapangan. Terjemahan J.S.Badudu. Yogyakarta: Kanisius.

Saeed, J. I. 1999. Lexical Semantics. Massachusets, USA: Blacwell Publishers

Sudaryanto. 1982. Metode Linguistik. Yogyakarta: Atma Pustaka UGM.

Sutjaja, I. G. M. 2005. Teks dan Rekayasa Teks. Dalam Linguistika Vol. 12, No. 22.

Denpasar: Program Studi Magister dan Doktor Linguistik Universitas Udayana.

Taulu, H. 1952. Hukum Adat Minahasa. Tomohon: Yayasan Membangun.

Turang, J. 1997. Profil Kebudayaan Minahasa. Tomohon: Majelis kebudayaan Minahasa.

Wardaugh, E. 1986. Introduction to Sociolinguistics. Oxford: Blackwell Publishers.

Warouw, M. 1985. Kamus Melayu Manado-Indonesia. Jakarta: Departemen Pendidikan Indonesia.

Weichart, G. 2004. Identitas Minahasa: Sebuah Praktik Kuliner. Dalam Jurnal Antropologi Indonesia: Tahun ke XXVIII No.74, Mei - Agustus 2004.

Wierzbicka, A. 1996. Semantics Primes and Universals. New York: Oxford University. 